\title{
Pengolahan Limbah Tulang Kambing Sebagai Produk Arang Aktif Menggunakan Proses Aktivasi Kimia dan Fisika
}

\author{
Sari Wardani ${ }^{1}$, Elvrida Rosa ${ }^{2}$, dan Rina Mirdayanti ${ }^{3}$ \\ ${ }^{1}$ Fakultas Pertanian, Universitas Abulyatama 1; e-mail: sariwardani peternakan@abulyatama.ac.id \\ 2Program Studi Agroteknologi, Fakultas Pertanian, Universitas Abulyatama, Indonesia \\ ${ }^{3}$ Program Studi Fisika. Fakultas Ilmu Dan Keguruan, Universitas Abulyatama, Indonesia
}

\begin{abstract}
ABSTRAK
Limbah pertanian merupakan hasil samping dari aktivitas pertanian yang saat ini masih dibuang langsung kelingkungan tanpa diproses atau diolah terlebih dahulu sehingga dampaknya terjadi penurunan kualitas lingkungan. Salah satu limbah pertanian yang banyak di temukan di Provinsi Aceh, khususnya kota Banda Aceh dan Aceh Besar adalah limbah tulang kambing. Limbah tulang kambing yang dihasilkan mencapai \pm 373 ton/tahun yang bersumber dari rumah pemotongan hewan, limbah rumah makan olahan daging kambing dan puncaknya pada saat tradisi meugang menyambut bulan puasa dan lebaran. Penelitian ini bertujuan untuk mengolah limbah tulang kambing menjadi produk arang aktif yang ramah lingkungan dengan menggunakan variasi proses aktivasi. Metode penelitian terdiri dari tiga tahapan proses, pertama proses preparasi arang dengan mengkarbonisasikan limbah tulang pada suhu $700^{\circ} \mathrm{C}$, kedua proses aktivasi arang yang dilakukan secara kimia dan fisika dan ketiga adalah analisa karakteristik arang aktif yang di bandingkan dengan Standar Nasional Indonesia (SNI). Hasil penelitian menunjukkan bahwa arang yang teraktivasi secara fisika mempunyai kualitas arang aktif lebih baik dari pada arang yang diaktivasi secara kimia. Kualitas arang aktif yang teraktivasi fisika yang terbaik adalah pada suhu aktivasi $700{ }^{\circ} \mathrm{C}$ dan kualitas arang aktif yang teraktivasi kimia yang terbaik adalah pada konsentrasi larutan zink klorida $1 \mathrm{~N}$. Kualitas arang aktif berbahan baku limbah tulang kambing mempunyai nilai kadar air sebesar 0,842 - 1,566 \%, nilai kadar abu sebesar 1,365 - 6,757 \%, nilai kadar zat mudah terbang sebesar 2,595 - 9,788 \%, nilai kadar karbon terikat sebesar 91,866 - 94,456 \%, daya serap iodium sebesar 825 - $968 \mathrm{mg} / \mathrm{g}$. Kualitas arang aktif berbahan baku limbah tulang kambing secara keseluruhan memenuhi SNI tentang arang aktif teknis dengan No. 06-3730-1995.
\end{abstract}

Kata kunci:Limbah tulang kambing, Arang aktif, Aktivasi kimia, Aktivasi fisika

\begin{abstract}
Agricultural waste is a byproduct of agricultural activities which is currently still discharged directly into the environment without prior processing so that it has an impact on the deterioration of environmental quality. One of the many agricultural wastes found in Aceh Province, especially the city of Banda Aceh and Aceh Besar is goat bone waste. The waste of goat bone produced reaches \pm 373 tons/year which is sourced from slaughterhouses, goat's food waste processed by goat meat and its peak when the tradition of meugang welcomes the fasting month and Eid. This study aims to process goat bone waste into environmentally friendly activated charcoal products using a variety of activation processes. The research method consisted of three stages of the process, first the process of charcoal preparation by carbonizing bone waste at a temperature of $700{ }^{\circ} \mathrm{C}$, both the charcoal activation process carried out chemically and physics and the last process of analyzing activated charcoal characteristics compared to the Indonesian National Standard (SNI). The best results of activated charcoal chemically activated characteristics are at the concentration of zinc chloride $3 \mathrm{~N}$ and the results of the activated charcoal characteristics of activated physics are best at an activation temperature of $700^{\circ} \mathrm{C}$. The results showed that charcoal which was activated physically had activated charcoal characteristics better than chemically activated charcoal. The results of activated charcoal characteristics include the value of moisture content of $0.842-1.566 \%$, ash content of $1.365-6.757 \%$, volatile matter of $2.595-9.788 \%$, fixed carbon content of $91.866-94.456 \%$, iodine absorption capacity of $825-968 \mathrm{mg} / \mathrm{g}$. The results of the characteristics of activated charcoal made from goat bone waste as a whole fulfilled SNI on technical activated charcoal with No. 06-3730-1995.
\end{abstract}

Keywords: Goat bone waste, Activated charcoal, Chemical activation, Physics activation

Citation: Wardani, S., Rosa, E., dan Mirdayanti, R. (2020). Pengolahan Limbah Tulang Kambing Sebagai Produk Arang Aktif Menggunakan Proses Aktivasi Kimia dan Fisika. Jurnal Ilmu Lingkungan, 18(1), 67-72, doi:10.14710/jil.18.1.67-72

\section{Pendahuluan}

Limbah pertanian adalah semua sisa dari proses hasil produksi pertanian. Limbah pertanian apabila dibuang langsung ke lingkungan dapat mencemari lingkungan dan mengganggu estetika. Limbah pertanian jika dikelola dan diolah secara terpadu dapat menghasilkan produk yang bernilai jual tinggi. Populasi ternak kambing secara nasional mengalami 
peningkatan sebanyak 1,94\% pada tahun 2018 dengan jumlah peningkatan populasi adalah 18,2 juta ekor jika dibandingkan pada Tahun 2017. Hal yang sama juga terjadi di Provinsi Aceh dimana jumlah populasi ternak kambing mengalami kenaikan sebesar 658.613 pada tahun 2018 sedangkan di Tahun 2017 populasi ternak sebesar 615,526 ekor. Dampak yang diakibatkan dari peningkatan jumlah populasi ternak adalah terjadinya peningkatan terhadap jumlah limbah yang dihasilkan salah satunya yaitu limbah tulang. Pengolahan terhadap limbah tulang saat ini belum dikelola secara maksimal (Juliasti, Legowo and Pramono, 2015).

Senyawa anorganik, organik yang terkadung dalam tulang kambing sebesar 69\% dan senyawa organik $22 \%$ selebihnya menrupakan kandungan air yaitu 9\%. Kolagen dapat diperoleh dari kandungan senyawa organik. Unsur karbon yang terkandung dalam senyawa kolagen dapat diproses lebih lanjut menjadi produk yang bernilai tinggi yaitu arang aktif. Arang aktif mempunyai manfaat yang sangat luas salah satunya sebagai bahan penyerap, sehingga karbon aktif termasuk ke dalam produk yang bernilai jual tinggi. Arang aktif dapat diproses dari limbah yang banyak mengandung senyawa organik yaitu tempurung kelapa, sekam padi, tulang binatang dan limbah lainnya yang banyak mengandung senyawa organik (Mohammad-Khah and Ansari, 2009; Arsad, 2017).

Pada lahan pertanian arang aktif dapat berfungsi sebagai penyerap bahan pencemar yang disebabkan dari penggunaan pupuk dan pestisida serta penyerapan logam berat dengan menggunakan teknik ameliorasi (E.S. Harsanti, SP., M.Sc; Dr. Asep Nugraha Ardiwinata, 2011). Bidang lainnya arang aktif dapat diaplikasikan sebagai sorbent yang mampu menyerap uap, logam berat serta sebagai katalisator pada proses pembuatan pupuk (Arsad and Hamdi, 2010). Arang hewan dikenal dengan nama abaiser atau tulang hitam. Tulang pada dasarnya merupakan pembentuk tubuh dan dukungan pada hewan yang membentuk komposit yang mengandung senyawa dari karbon, kalsium, magnesium dan bahan anorganik lainnya (Mohammed et al., 2012).

Tulang dapat diolah menjadi produk yang bernilai jual yaitu arang aktif, beberapa penelitian telah membuktikan bahwa limbah tulang hewan dapat diolah menjadi arang aktif dengan berbagai perlakuan aktivasi. Limbah tulang domba yang teraktivasi $\mathrm{ZnCl}_{2}$ mampu menyerap merkuri dengan volume pori yaitu 83,98 m/g (Dawlet et al., 2013). Limbah tulang ayam, anjing, sapi dan kambing yang teraktivasi hidrogen klorida pada konsentrasi $2 \mathrm{M}$ mampu menyerap warna pada minyak sawit, hasil analisa memperlihatkan bahwa arang aktif tulang ayam mampu menyerap sebesar 275 , arang aktif tulang kambing sebesat 268, arang aktif tulang anjing sebesar 261 dan arang aktif tulang sapi sebesar 220 (Mohammed et al., 2012). Arang aktif tulang sapi yang diaktivasi secara kimia menggunakan larutan natrium karbonat dapat menyerap logam tembaga sebesar 99,65\% (Previanti et al., 2017). Arang aktif tulang kambing yang telah diaktivasi menggunakan larutan asam sulfat $3 \mathrm{~N}$ mampu menyerap senyawa Iodium sebesar 983 mg/g (Wardani and Rosa, 2018). Arang aktif tulang sapi diaplikasikan sebagai bahan penyerap kromium heksavalen di dalam air (Ghanizadeh et al., 2012). Arang aktif berbahan baku tulang kambing mampu menyerap iodium sebesar $926 \mathrm{mg} / \mathrm{g}$ dengan menggunakan suhu aktivasi $500^{\circ} \mathrm{C}$ selama 1 jam (Wardani and Mirdayanti, 2019).

Penelitian-penelitian terdahulu mengolah limbah hasil pertanian seperti kulit singkong, kulit buah coklat, pelepah aren, kulit durian, cangkang kelapa sawit dan limbah pertanian lainnya sebagai bahan baku dasar pembuatan arang aktif, sedangkan arang aktif berbahan baku limbah tulang hewan khususnya limbah tulang kambing masih sangat sedikit yang mengolahnya. Berdasarkan uraian diatas maka penelitian ini bertujuan untuk mengolah limbah tulang kambing sebagai alternatif bahan baku arang aktif yang ramah lingkungan dengan menggunakan proses aktivasi secara kimia dan fisika.

\section{Metode Penelitian}

Bahan baku arang aktif yaitu limbah tulang kambing telah dikumpulkan berasal dari limbah rumah makan olahan daging kambing dan rumah pemotongan hewan pada kabupaten Aceh Besar dan Kota Banda Aceh. Penelitian ini menggunakan bahan bahan yang terdiri dari aquadest, kertas saring whatman, larutan iodine dengan normalitas 0,1 , Natrium Thiosulfat dengan normalitas 0,1 dan Indikator amilum 1 persen dan larutan zink klorida pada konsentrasi $1 \mathrm{~N}, 2 \mathrm{~N}$ dan $3 \mathrm{~N}$. Peralatan penelitian terdiri dari gelas beker (pyrex), gelas ukur (pyrex), batang pengaduk, corong gelas, pipet tetes, pipet ukur, hot plate magnetic stirrer, oven, furnace, desikator, timbangan, ayakan mesh, masker, sarung tangan, buret, statif dan centrifuge.

Variabel tetap pada penelitian ini adalah berat arang tulang kambing (10 gr) untuk setiap perlakuan, waktu karbonisasi 20 menit, suhu karbonisasi $700^{\circ} \mathrm{C}$, ukuran mesh arang 100, waktu aktivasi arang 1 jam. Variabel berubah terdiri dari proses aktivasi yaitu aktivasi secara kimia menggunakan larutan $\mathrm{ZnCl}_{2}$ dengan konsentrasi $1 \mathrm{~N}, 2 \mathrm{~N}$ dan $3 \mathrm{~N}$. Proses aktivasi secara fisika pada suhu $500^{\circ} \mathrm{C}, 600^{\circ} \mathrm{C}$ dan $700^{\circ} \mathrm{C}$.

Proses pembuatan arang aktif berbahan baku limbah tulang kambing terdiri dari beberapa tahapan proses yaitu preparasi bahan baku, karbonisasi tulang, aktivasi arang tulang dan uji karakteristik arang aktif tulang kambing.

a. Preparasi Limbah Tulang Kambing

Limbah tulang kambing yang sudah terkumpulkan kemudian dibersihkan dari sisa daging yang masih melekat, dicuci hingga bersih dan dijemur menggunakan sinar matahari sampai kering 
selanjutnya di panaskan kembali di dalam oven yang bertujuan untuk mengurangi sisa kandungan air yang masih terdapat pada tulang.

b. Proses Karbonisasi

Proses penguraian selulosa organik dapat dilakukan dengan menggunakan proses karbonisasi pada suhu $600^{\circ} \mathrm{C}-800^{\circ} \mathrm{C}$ sehingga akan menghasilkan unsur karbon yang disertai dengan pelepasan unsur unsur non-karbon (Meisrilestari, Khomaini and Wijayanti, 2013; Arsad, 2017). Limbah Tulang kambing yang telah kering selanjutnya diambil sebayak 500 gr dan dilakukan pengecilan ukuran hingga berukuran $3 \mathrm{~cm}$ dan selanjutnya arang dikarbonisasi pada suhu $700^{\circ} \mathrm{C}$ selama 2 jam.

c. Proses Aktivasi

Arang Limbah tulang kambing yang telah dikarbonisasi selanjutnya akan diaktivasi menggunakan proses aktivasi secara kimia dan fisika. Proses aktivasi secara kimia mengikuti prosedur berikut ini merendam serbuk arang masing-masing sebanyak $10 \mathrm{~g}$ kedalam larutan zink klorida pada konsentrasi aktivator $1 \mathrm{~N}, 2 \mathrm{~N}$ dan $3 \mathrm{~N}$ masing-masing sebanyak $100 \mathrm{~mL}$ di dalam Beaker gelas $250 \mathrm{~mL}$, diaduk selama 5 menit dan didiamkan 24 jam. Kemudian disaring dan selanjutnya dipanaskan pada suhu $800^{\circ} \mathrm{C}$ selama 15 menit. Arang kemudian dicuci sampai pH netral dan dikeringkan selama 15 menit menggunakan oven, selanjutnya didinginkan di dalam desikator. Proses aktivasi secara fisika mengikuti prosedur berikut arang ditimbang masing - masing sebanyak 100 gr, kemudian dimasukkan kedalam furnace untuk dilakukan tahap aktivasi selama satu jam pada suhu $500^{\circ} \mathrm{C}, 600^{\circ} \mathrm{C}$ dan $700^{\circ} \mathrm{C}$.

d. Karakteristik Arang Aktif Tulang Kambing

Arang tulang kambing yang telah teraktivasi secara kimia dan fisika berikutnya akan dilakukan analisa karakteristik arang aktif meliputi uji kandungan kadar air, kadar abu, kemampuan daya serap iodium, zat menguap dan kandungan karbon. Prosedur analisa karakteristik arang aktif sesuai proses pengujian SNI 06-3730-1995 tentang arang aktif teknis meliputi:

Arang aktif tulang kambing diambil sebanyak 1 gram diletakkan diatas kertas saring yang sudah diketahui beratnya dan dipanaskan di dalam oven pada suhu $105^{\circ} \mathrm{C}$ selama 3 jam, selanjutnya sampel didinginkan didalam desikator dan ditimbang untuk mendapatkan nilai kadar air dari arang aktif tersebut. Uji kadar abu mengikuti prosedur seperti berikut cawan porselin kosong ditimbang dan dicatat beratnya selajutnya ditambahkan sebanyak 1 gram sampel arang aktif kedalam cawan porselin tersebut. Cawan yang berisi arang aktif dipanaskan didalam furnace sampai menjadi abu pada suhu $750^{\circ} \mathrm{C}$ selama satu jam, arang yang telah diabukan kemudian didinginkan didalam desikator dan ditimbang agar diketahui nilai kadar abunya.

Uji kadar volatil matter dilakukan sesuai prosedur berikut diambil cawan porselin, ditimbang 69 serta dicatat beratnya selanjutnya ditambahkan sebanyak 1 gram sampel arang aktif kedalam cawan porselin tersebut dan dipanaskan didalam furnace pada suhu $900^{\circ} \mathrm{C}$ selama 7 menit, didinginkan di dalam desikator dan ditimbang serta dicatat beratnya. Analisa kadar fixed carbon berdasarkan perhitungan jumlah kadar air ditambah kadar abu dan kadar zat terbang kemudian di kurangi seratus.

Analisa kemampuan arang menyerap senyawa iodium mengikuti tahapan berikut ini arang aktif sebanyak 1 gram dipanaskan didalam oven selama 1 jam pada suhu $105^{\circ} \mathrm{C}$. Arang aktif yang telah dipanaskan kemudian ditimbang sebanyak 0,5 gram dan ditambahkan larutan iodium pada Normalitas 0,1 sebanyak $50 \mathrm{ml}$ dan dilakukan pengadukan selama 15 menit dan disentrifugal untuk memisahkan filtrat dan endapan. Sebanyak $10 \mathrm{~mL}$ filtrat diambil dan disimpan didalam erlenmeyer untuk dilakukan proses titrasi menggunakan larutan natrium tiosulfat 0,1 N. Selama proses titrasi apabila filtrat telah berwarna kuning samar selanjutnya ditambahkan larutan amilum 1\% sebanyak $1 \mathrm{ml}$. Proses titrasi dihentikan apabila warna biru telah hilang.

\section{Hasil dan Pembahasan}

\subsection{Karakteristik arang tulang kambing}

Arang tulang kambing diperoleh setelah proses karbonisasi. Proses karbonisasi bertujuan untuk menghilangkan unsur oksigen dan hidrogen yang masih terdapat didalam karbon sehingga dapat membentuk kerangka karbon yang baru dengan tingkat kemurnian yang tinggi (Mizwar, 2018). Karakteristik arang tulang kambing yang dipelajari adalah uji kadar air, kadar abu, volatile matter, ficed carbon dan daya serap iodium masih memenuhi standar nasional Indonesia tentang arang. Karakteristik arang tulang kambing ditampilkan pada Tabel 1.

Tabel 1. Karakteristik Arang Tulang Kambing

\begin{tabular}{lc}
\hline \multicolumn{1}{c}{ Karaktersitik } & Arang Tulang Kambing \\
\hline Kadar Air (\%) & 0,959 \\
Kadar Abu (\%) & 15,411 \\
Volatile Matter (\%) & 14,626 \\
Ficed Carbon (\%) & 82,454 \\
Daya Serap Iodium (mg/g) & 920,025 \\
\hline
\end{tabular}

Sumber data diolah dari hasil penelitian

\subsection{Karakteristik arang aktif tulang kambing teraktivasi kimia}

Kemampuan arang aktif dalam menyerap polutan atau zat pencemar sangat ditentukan dari proses aktivasi arang tersebut. Proses aktivasi pada arang dapat dilakukan secara kimia maupun fisika. Proses aktivasi bertujuan untuk meningkatkan luas permukaan arang aktif yang ditandai dengan hilangnya zat pengotor yang menutupi pori - pori arang ikut menguap atau terlepas selama proses aktivasi berlangsung sehingga kemampuan arang aktif dalam menyerap zat polutan semakin meningkat, 
sedangkan arang hasil proses karbonisasi masih memiliki kemampuan penyerapan yang lebih rendah, hal ini disebabkan karena pada pori - pori permukaan arang masih mengandung senyawa pengotor (Idrus, Lapanporo and Putra, 2013). Proses aktivasi kimia bertujuan untuk memutuskan rantai karbon dari senyawa organik, sehingga volume dan diameter pori pada arang menjadi semakin luas (Sembiring and Sinaga, 2003).

Tabel 2. memperlihatkan arang aktif yang teraktivasi secara kimia menggunakan variasi konsentrasi larutan $\mathrm{ZnCl}_{2}$ terhadap karakteristik arang aktif tulang kambing. Hasil penelitian menunjukkan karakteristik arang aktif yang teraktivasi larutan $\mathrm{ZnCl}_{2}$ masih memenuhi SNI 063730-1995 tentang arang aktif teknis. Tinggi rendahnya nilai kadar untuk masing - masing karakteristik sangat ditentukan dari konsentrasi aktivator serta proses pencucian setelah aktivasi. Hasil penelitian menunjukkan bahwa semakin tinggi konsentrasi suatu aktivator maka karakteristik arang aktif semakin bagus, sehingga kemampuan arang aktif dalam menyerap iodium semakin meningkat yaitu sebesar $958 \mathrm{mg} / \mathrm{g}$ pada konsentrasi $3 \mathrm{~N}$, sedangkan pada konsentrasi $1 \mathrm{~N}$ arang aktif hanya mampu menyerap $952 \mathrm{mg} / \mathrm{g}$.
Beberapa Penelitian terkait pengaruh konsentrasi aktivator terhadap kualitas arang aktif telah banyak di teliti, seperti penelitian berikut ini yang menyatakan bahwa peningkatan konsentrasi $\mathrm{ZnCl}_{2}$ dari $20 \%$ sampai dengan $40 \%$ menunjukkan peningkatan luas permukaan arang sebesar 0,278 $\mathrm{m}^{2} / \mathrm{g}$ sehingga kemampuan arang aktif dalam menyerap adsorbat semakin baik (Du et al., 2016). Peningkatan jumlah $\mathrm{ZnCl}_{2}$ akan meningkatkan luas permukaan serta diikuti dengan peningkatan volume pori arang aktif, yang menghasilkan arang dengan jumlah pori yang banyak (Erdem et al., 2016).

Arang aktif berbahan baku tempurung kelapa yang diaktivasi menggunakan aktivator $\mathrm{ZnCl}_{2}$ menunjukkan bahwa semakin tinggi konsentrasi aktivator maka daya serap arang aktif terhadap fenol semakin tinggi yaitu $171,233 \mathrm{mg} / \mathrm{g}$ pada konsentrasi aktivator 7,5\% sedangkan pada konsentrasi aktivator 2,5\% dan 5\% arang hanya mampu menyerap kandungan fenol sebesar 131,406 mg/g dan 150,830 $\mathrm{mg} / \mathrm{g}$ (Pambayun et al., 2013). Penelitian lainnya juga menyatakan bahwa semakin tinggi konsentrasi aktivator $\mathrm{ZnCl}_{2}$ maka daya serap terhadap iodium semakin meningkat yaitu $970 \mathrm{mg} / \mathrm{g}$ pada konsentrasi 8\% (Prasetyo and Nasrudin, 2013). Produk arang aktif limbah tulang kambing yang diaktivasi secara kimia ditampilkan pada Gambar 1.

Tabel 2. Karakteristik Arang Aktif Tulang Kambing Teraktivasi Kimia

\begin{tabular}{|c|c|c|c|c|c|c|c|}
\hline \multirow{2}{*}{ Karaktersitik } & \multicolumn{3}{|c|}{ Hasil Penelitian } & \multicolumn{3}{|c|}{ Hasil Penelitian Lain } & \multirow{2}{*}{ SNI } \\
\hline & $\begin{array}{c}\mathrm{ZnCl}_{2} \mathrm{IN} \\
\text { (a) }\end{array}$ & $\begin{array}{c}\mathrm{ZnCl}_{2} 2 \mathrm{~N} \\
\text { (a) }\end{array}$ & $\mathrm{ZnCl}_{2} 3 \mathrm{~N}(\mathrm{a})$ & $\begin{array}{c}\mathrm{ZnCl}_{2} 8 \% \\
\text { (b) }\end{array}$ & $\begin{array}{c}\mathrm{ZnCl}_{2} \mathrm{O}, 02 \mathrm{M} \\
\text { (c) }\end{array}$ & $\begin{array}{c}\mathrm{ZnCl}_{2} 0,1 \mathrm{M} \\
\text { (d) }\end{array}$ & \\
\hline Kadar Air (\%) & 0,958 & 0,842 & 1,091 & 1,525 & 5 & 5 & $\operatorname{Max} 15$ \\
\hline Kadar Abu (\%) & 3,729 & 1,351 & 1,718 & 53,678 & 7,33 & 8,33 & $\operatorname{Max} 10$ \\
\hline Volatile Matter (\%) & 3,055 & 1,834 & 2,651 & 33,441 & 6 & 7,36 & $\operatorname{Max} 25$ \\
\hline Ficed Carbon (\%) & 94 & 95 & 94 & - & 81 & 79 & Min 65 \\
\hline Daya Serap Iodium (mg/g) & 952 & 954 & 958 & 970 & 1091 & 788 & Min 750 \\
\hline
\end{tabular}

(a) Sumber data diolah dari hasil penelitian; (b) (Prasetyo and Nasrudin, 2013); (c) (Manurung, Ratnayani and Prawira, 2019); (d) (Sahara, Permatasaari and Suarsa, 2019)

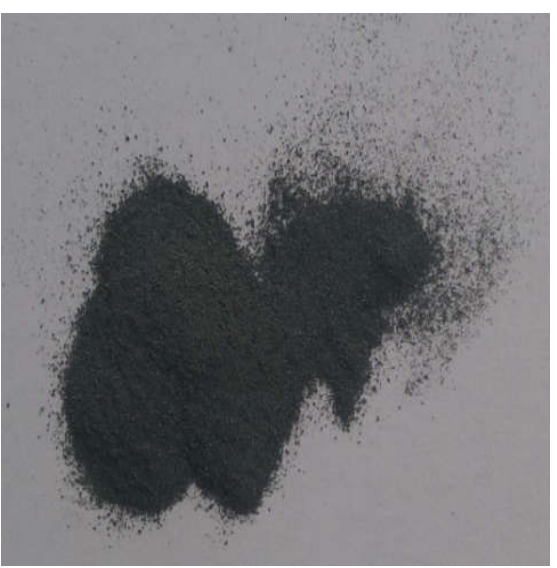

(a)

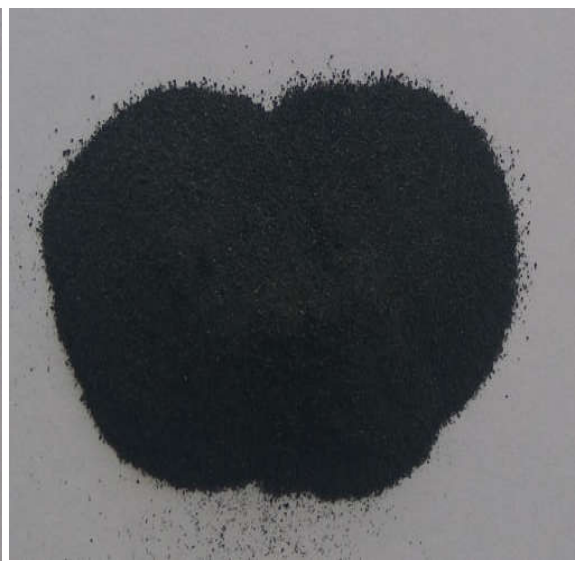

(b)

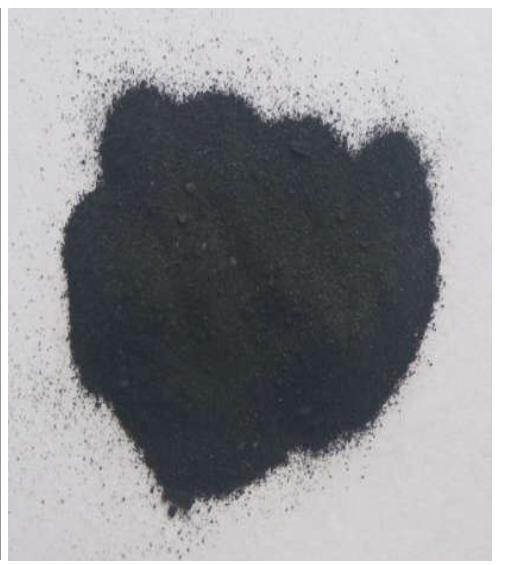

(c)

Gambar 1. Produk Arang Aktif Yang Teraktivasi Secara Kimia, (a) $\mathrm{ZnCl}_{2} 1 \mathrm{~N}$; (b) $\mathrm{ZnCl}_{2} 2 \mathrm{~N}$; (c) $\mathrm{ZnCl} 23 \mathrm{~N}$

\subsection{Karakteristik arang aktif tulang kambing teraktivasi fisika}

Aktivasi fisika bertujuan untuk memutuskan rantai karbon dari senyawa organik dengan menggunakan bantuan panas, uap dan $\mathrm{CO}_{2}$ (Sembiring and Sinaga, 2003). Temperatur aktivasi sangat mempengaruhi massa arang aktif, semakin tinggi temperatur aktivasi maka massa arang aktif yang 
dihasilkan akan semakin berkurang dan jumlah kadar air yang terkandung dalam arang aktif akan semakin rendah akibat terjadinya proses penguapan selama proses aktivasi arang (Mody, 2014). Pengujian kadar air bertujuan untuk mengetahui banyaknya air yang dapat teruapkan sehingga air yang terikat pada arang tidak menutupi pori-pori arang aktif (Prasetyo and Nasrudin, 2013). Semakin banyak molekul air yang teruapkan maka pori-pori arang aktif akan semakin besar dan luas permukaan menjadi semakin meningkat, hal ini akan berpengaruh terhadap kemampuan daya serap arang sebagai bahan penyerap (Prasetyo and Nasrudin, 2013). Rendahnya kadar air dapat dikarenakan permukaan arang aktif lebih sedikit mengandung gugus fungsi yang bersifat polar sehingga interaksi antara uap air yang bersifat polar juga sedikit (Prasetyo and Nasrudin, 2013). Pengujian kadar abu berfungsi untuk mengetahui kandungan mineral yang terdapat dalam arang aktif (Pembayun, G. S., Yulianto, R. Y. E., Rachimoellah, M., dan Putri, 2013). Arang aktif tersusun dari lapisan lapisan yang saling menumpuk satu sama lain sehingga membentuk pori. Umumnya pori - pori pada arang aktif mengandung senyawa pengotor yang berupa mineral anorganik dan dan oksida logam (Sembiring and Sinaga, 2003). Selama proses aktivasi berlangsung mineral yang terkandung dalam arang aktif ikut menguap sehingga luas permukaan pori pori arang aktif bertambah besar. Pengujian daya serap iodium bertujuan untuk melihat kemampuan arang aktif sebagai bahan penyerap. Semakin tinggi angka iod maka semakin bagus kualitas arang aktif sehingga arang secara maksimal mampu mengadsopsi zat terlarut (Darmawan, Pari and Sofyan, 2009)

Tabel 3. Memperlihatkan karakteristik arang aktif tulang kambing teraktivasi fisika. Hasil penelitian menunjukkan bahwa semakin tinggi suhu aktivasi maka kemampuan penyerapan iodium semakin tinggi yaitu $968 \mathrm{mg} / \mathrm{g}$ pada suhu $700^{\circ} \mathrm{C}$. Hasil penelitian ini juga sesuai dengan hasil penelitian telah dilakukan pada pembuatan arang aktif berbahan baku tempurung kepala, dimana semakin tinggi suhu aktivasi maka penyerapan iodium semakin tinggi, hal ini di karenakan semakin banyak senyawa pengotor yang terlepas dari permukaan arang aktif seiring dengan peningkatan suhu aktivasi, sehingga luas permukaan arang semakin besar dan kemampuan arang dalam menyerap iodium semakin meningkat (Idrus, Lapanporo and Putra, 2013). Penelitian lainnya juga menyatakan bahwa semakin suhu ditingkatkan maka kualitas arang dalam menyerap iodium semakin baik, hal ini sesuai dengan penelitian terhadap Serbuk arang kulit kemiri yang diaktivasi dengan menggunakan larutan $\mathrm{H}_{3} \mathrm{PO}_{4}$ dengan konsentrasi 2,5\% selama 24 jam dan disintering pada suhu $200^{\circ} \mathrm{C}, 250^{\circ} \mathrm{C}, 300^{\circ} \mathrm{C}, 350^{\circ} \mathrm{C}$ dan $400^{\circ} \mathrm{C}$, hasil penelitian menyatakan bahwa kualitas karbon aktif yang terbaik diperoleh pada suhu $400{ }^{\circ} \mathrm{C}$ dengan kadar air 14,35 \%, kadar abu 8,5\%, daya serap terhadap kadar iod sebesar 252,97 mg/g (Etni Laos and Yulianti, 2017). Gambar 2 memperlihatkan produk arang aktif dari limbah tulang kambing yang diaktivasi secara fisika.

Tabel 3. Karakteristik Arang Aktif Tulang Kambing Teraktivasi Fisika

\begin{tabular}{lccccccc}
\hline \hline \multirow{2}{*}{ Karaktersitik } & \multicolumn{3}{c}{ Hasil Penelitian } & \multicolumn{3}{c}{ Hasil Penelitian Lain } & SNI \\
\cline { 2 - 6 } & $500{ }^{\circ} \mathrm{C}(\mathrm{a})$ & $600{ }^{\circ} \mathrm{C}(\mathrm{a})$ & $700^{\circ} \mathrm{C}(\mathrm{a})$ & $500{ }^{\circ} \mathrm{C}(\mathrm{b})$ & $600{ }^{\circ} \mathrm{C}(\mathrm{c})$ & $700{ }^{\circ} \mathrm{C}(\mathrm{d})$ & \\
\hline Kadar Air (\%) & 1,396 & 1,457 & 1,566 & 5,972 & 3,2 & 3,34 & Max 15 \\
Kadar Abu (\%) & 4,124 & 6,419 & 6,757 & 8,655 & 0,25 & 3,72 & Max 10 \\
Volatile Matter (\%) & 4,252 & 5,144 & 9,619 & 0,805 & - & 10,34 & Max 25 \\
Ficed Carbon (\%) & 93 & 92 & 87 & 90 & - & 85 & Min 65 \\
Daya Serap Iodium (mg/g) & 825 & 895 & 968 & 908 & 460 & 544 & Min 750 \\
\hline
\end{tabular}

(a)Sumber data diolah dari hasil penelitian; (b) (Rosalina, Tun.T, Etty. R and Sri.S) (2016); (c) (Idrus, Lapanporo and Putra, 2013) (d) (Polii, 2017)

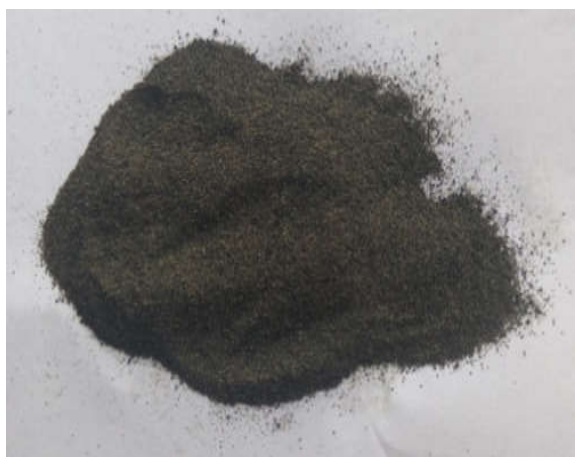

(a)

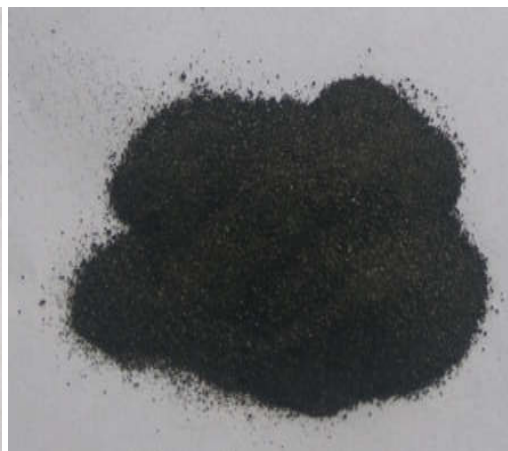

(b)

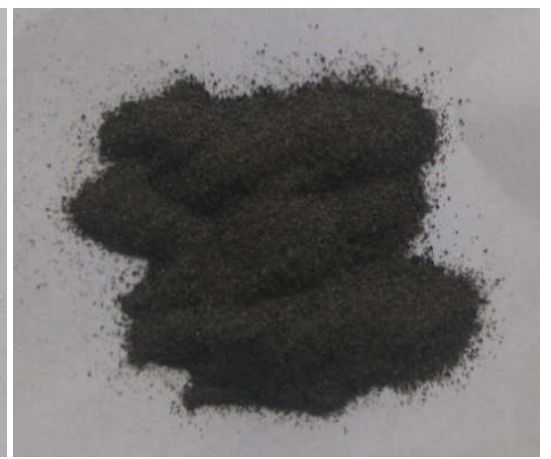

(c)

Gambar 2. Produk Arang Aktif Yang Teraktivasi Secara Fisika, (a) $500^{\circ} \mathrm{C}$; (b) $600{ }^{\circ} \mathrm{C}$; (c) $700^{\circ} \mathrm{C}$ 


\section{Kesimpulan}

Pengolahan limbah pertanian khususnya limbah tulang hewan yang diproses lebih lanjut dapat menghasilkan produk tepat guna yaitu arang aktif yang dapat diaplikasikan dalam proses penyerapan limbah. Proses aktivasi yang terbaik adalah menggunakan aktivasi secara fisika dengan penyerapan Iodium sebesar $968 \mathrm{mg} / \mathrm{g}$ pada suhu $700^{\circ} \mathrm{C}$.

\section{Ucapan Terima Kasih}

Universitas abulyatama yang telah memberikan dukungan serta Direktorat Riset dan Pengabdian Masyarakat Direktorat Jenderal Penguatan Riset dan Pengembangan Kementerian Riset, Teknologi dan Pendidikan Tinggi yang telah memberikan bantuan dana hibah penelitian pada skim Penelitian Dosen Pemula tahun anggaran 2018 dan 2019.

\section{DAFTAR PUSTAKA}

Arsad, E. (2017) 'Teknologi Pengolahan Dan Pemanfaatan Karbon Aktif Untuk Industri', Jurnal Riset Industri Hasil Hutan. doi: 10.24111/jrihh.v2i2.1146.

Arsad, E. and Hamdi, S. (2010) 'Teknologi pengolahan dan pemanfaatan karbon aktif untuk industri', Jurnal Riset Hasil Industri Hutan.

Darmawan, S., Pari, G. and Sofyan, K. (2009) 'Optimasi Suhu dan Lama Aktivasi dengan Asam Phosfat dalam Produksi Arang Aktif Tempurung Kemiri', Ilmu dan Teknologi Hasil Hutan.

Dawlet, A. et al. (2013) 'Removal of Mercury from Aqueous Solution Using Sheep Bone Charcoal', Procedia Environmental Sciences. Elsevier B.V., 18, pp. 800808. doi: 10.1016/j.proenv.2013.04.108.

$\mathrm{Du}, \mathrm{X}$. et al. (2016) 'Effect of $\mathrm{ZnCl} 2$ impregnation concentration on the microstructure and electrical performance of ramie-based activated carbon hollow fiber', Ionics. doi: 10.1007/s11581-0151571-3.

E.S. Harsanti, SP., M.Sc; Dr. Asep Nugraha Ardiwinata, Ms. (2011) 'Arang Aktif Meningkatkan Kualitas Lingkungan', Agroinovasi, Badan Litbang Pertanian.

Erdem, M. et al. (2016) 'Preparation and Characterization of a Novel Activated Carbon from Vine Shoots by $\mathrm{ZnCl} 2$ Activation and Investigation of Its Rifampicine Removal Capability', Water, Air, and Soil Pollution. doi: 10.1007/s11270-016-2929-5.

Etni Laos, L. and Yulianti, I. (2017) 'Pengaruh Suhu Aktivasi Terhadap Daya Serap Karbon Aktif Kulit Kemiriv', in. doi: 10.21009/0305020226.

Ghanizadeh, G. et al. (2012) 'Kinetics and isotherm studies of hexavalent chromium adsorption from water using bone charcoal', Fresenius Environmental Bulletin, 21(5 A), pp. 1296-1302.

Idrus, R., Lapanporo, B. P. and Putra, Y. S. (2013) 'Pengaruh Suhu Aktivasi Terhadap Kualitas Karbon Aktif Berbahan Dasar Tempurung Kelapa', PRISMA FISIKA. doi: 10.1371/journal.pone.0023032.

Juliasti, R., Legowo, A. M. and Pramono, Y. B. (2015) 'Pemanfaatan Limbah Tulang Kaki Kambing sebagai Sumber Gelatin dengan Perendaman Menggunakan Asam Klorida', Jurnal Aplikasi Teknologi Pangan. doi: 10.17728/jatp.2015.01.
Manurung, M., Ratnayani, O. and Prawira, R. A. (2019) 'Sintesis dan Karakterisasi Arang dari Limbah Bambu dengan Aktivator $\mathrm{ZnCl2',} \mathrm{cakra} \mathrm{Kimia}$ (Indonesia E-Journal of Applied Chemistry).

Meisrilestari, Y., Khomaini, R. and Wijayanti, H. (2013) 'Pembuatan Arang Aktif dari Cangkang Kelapa Sawit dengan Aktivasi Secara Fisika, Kimia dan Fisika dan Kimia', Konversi. doi: 10.20527/K.V2I1.136.

Mizwar, A. (2018) 'Aktivasi Kimia-Fisik Limbah Serutan Rotan Menjadi Karbon Aktif', Jurnal Purifikasi. doi: 10.12962/j25983806.v14.i1.13.

Mody, L. (2014) 'Pembuatan Dan Kegunaan Arang Aktif', Info Teknis EBONI.

Mohammad-Khah, A. and Ansari, R. (2009) 'Activated charcoal: Preparation, characterization and applications: A review article', International Journal of ChemTech Research.

Mohammed, A. et al. (2012) 'A Comparative Analysis and Characterization of Animal Bones as Adsorbent', Pelagia Research Library Advances in Applied Science Research, 3(5), pp. 3089-3096. Available at: www.pelagiaresearchlibrary.com.

Pambayun, G. S. et al. (2013) 'Pembuatan Karbon Aktif Dari Arang Tempurung Kelapa Dengan Aktivator Zncl2 Dan Na2co3 Sebagai Adsorben Untuk Mengurangi Kadar Fenol Dalam Air Limbah', Jurnal Teknik ITS. doi: 10.12962/j23373539.v2i1.2437.

Pembayun, G. S., Yulianto, R. Y. E., Rachimoellah, M., dan Putri, M. M. (2013) 'Pembuatan Karbon Aktif Dari Arang Tempurung Kelapa Dengan Aktivator Zncl2 Dan Na2co3 Sebagai Adsorben Untuk Mengurangi Kadar Fenol Dalam Air Limbah', Jurnal Teknik ITS. doi: 10.12962/j23373539.v2i1.2437.

Polii, F. F. (2017) 'Pengaruh suhu dan lama aktivasi terhadap mutu arang aktif dari kayu kelapa', Jurnal Industri Dan Hasil Perkebunan.

Prasetyo, Y. and Nasrudin, H. (2013) 'Penentuan Konsentrasi Zncl2 Pada Proses Pembuatan Karbon Aktif Tongkol Jagung Dan Penurunan Konsentrasi Surfaktan Linier Alkyl Benzene Sulphonate (Las) Determination', UNESA Journal of Chemistry.

Previanti, P. et al. (2017) 'Daya Serap Dan Karakterisasi Arang Aktif Tulang Sapi Yang Teraktivasi Natrium Karbonat Terhadap Logam Tembaga', Chimica et Natura Acta. doi: 10.24198/cna.v3.n2.9182.

Rosalina, Tun, T., Etty, R. and Sri, S. (2016) 'Pengaruh Aktivasi Fisika Dan Kimia Arang Aktif Buah Bintaro TErhadap Daya Serap Logam Berat Krom', Jurnal Biopropal Industri

Sahara, E., Permatasaari, D. E. and Suarsa, I. W. (2019) 'Pembuatan Dan Karakterisasi Arang Aktif Dari Batang Limbah Tanaman Gumitir Dengan Aktivator Zncl2', Jurnal Kimia. doi: 10.24843/jchem.2019.v13.i01.p15.

Sembiring, M. T. and Sinaga, T. S. (2003) Arang Aktif (Pengenalan dan Proses Pembuatannya), USU Digital Library.

Wardani, S. and Mirdayanti, R. (2019) 'Optimasi Suhu Aktivasi Proses Pembuatan Arang Aktif Limbah Tulang Kambing', Jurnal Serambi Engineering. doi: 10.32672/jse.v4i2.1327.

Wardani, S. and Rosa, E. (2018) 'Potensi Limbah Tulang Kambing Sebagai Arang Aktif Yang Teraktivasi Asam Sulfat', Jurnal Serambi Engineering, 3(2), pp. 308315. doi: 10.32672/jse.v3i2.714. 